\title{
Long-run asymmetric association between FDI and productivity in Turkey*
}

\author{
Yüksel Okşak ${ }^{1}$, Cüneyt Koyuncu ${ }^{2}$
}

\begin{abstract}
Incoming foreign direct investments (FDI) may enhance the productivity level of the host country by bringing new advanced technologies. On the other hand, the nexus of FDI and productivity, rather than being linear, might be nonlinear because the effect of increases and decreases in FDI on productivity may not be symmetric. In this sense, this study investigates the asymmetric relationship between FDI and productivity in Turkey by using two different productivity indicators (i.e., PROD1 and PROD2) and employing a Nonlinear ARDL approach. Our hypothesis claims there is an asymmetric association between FDI and productivity in the long run in Turkey. Nonlinear cointegration test findings indicate that selected variables are cointegrated. Hence, they move together in the long run. Our study uses aggregated data at the macro level to analyze the longterm asymmetric relationship between foreign direct investment and labor productivity in Turkey using the NARDL estimation technique. Concerning the estimation results, a long-run nonlinear relationship between incoming FDI and labor productivity was detected, and this finding remained valid across two models constructed by using two distinct labor productivity indicators. As a whole, our results are consistent with the ones found in the literature. Besides, for the first time in the literature, this study addresses the long-run asymmetric nexus between FDI and labor productivity by using macro-level data specific to Turkey and makes various policy recommendations.
\end{abstract}

Key words: productivity, FDI, working hours, investment, GDPPC, NARDL

JEL classification: C22, E22, F21, J24

\footnotetext{
* Received: 02-04-2020; accepted: 08-11-2021

1 Assoc. Prof., Inegöl Faculty of Business, Department of International Trade and Business, Bursa Uludăg University, 16400 İnegöl/Bursa. Scientific affiliation: macroeconomic development, growth, employment, econometric modelling. ORCID: 0000-0001-8794-4597.yukseloksak@ uludag.edu.tr.

2 Prof., Faculty of Economics and Administrative Sciences, Department of Economics, Bilecik Şeyh Edebali University, 11230 Merkez/Bilecik. Scientific affiliation: applied economics, panel analysis, econometric modelling. ORCID: 0000-0002-8638-2761.cuneyt.koyuncu@bilecik.edu.tr.
} 


\section{Introduction}

There are studies emphasizing that foreign direct investment (FDI) contributes to growth and productivity in different ways. Foreign direct investments and foreign trade are efficient tools for accumulating capital and creating employment. Studies reveal that multinational companies are more efficient and contribute much more to the global value chain than national companies. More advanced technologies transferred via multinationals can lead to the spread of R\&D and know-how in the local economy. Incoming FDI can increase the efficiency level of the host country by introducing new advanced technologies that are more effective and efficient than the previous ones in the country.

FDIs contribute critically to developing countries' ability to transfer information and technology. FDI provides the home country with cheap labor and energy while it provides the host country with an accelerating effect on development and economic growth. Thus, it contributes to the development of the total investment amount and hence the economic activity of the host country. FDI has the role of the leading determinant of foreign capital inflows. (Carp, 2013). When we examine the studies dealing with the relationship between FDI and labor, it is possible to say that they focus on country, wage level, employment, labor market flexibility, and sectoral studies. Hence, at the aggregate level, FDI contributes to economic growth in North Africa, in turn generating additional revenues for governments and populations in the region through fiscal policies and jobs creation (Soumare, 2015). For example, Rong et al. (2020) observe a positive employment impact of FDI, with labor market flexibility playing an important positive regulatory role. Another empirical study (Hübler and Keller, 2010) does not confirm the hypothesis that total FDI inflows reduce the energy intensity of developing countries. On the contrary, external development assistance reveals that it is related to energy efficiency gain. Empirical results found by Zhang (2005) pinpoint the fact that Hong Kong-Taiwan direct investments are mainly motivated by cheap labor costs.

The underlying fact is that FDI is an investment type that promises much more stability than capital market investments since FDI is such an investment with limited mobility. In this context, attracting FDI to the country is one of the main targets of developing countries (Nistor, 2015; Flora, 2017). There is an opinion that the FDI surge will increase the internal growth of the economies of developing countries. The competition between FDI companies and domestic companies, as believed, will create research and development, technological infrastructure, competitiveness, efficiency and institutional capacity increases (Osano and Koine, 2016; Eller et al., 2006). That is why, studies on the impact of FDI increases on the productivity levels of host countries are gaining importance.

When we look at empirical studies on the FDI, it is possible to say that there are three different elements related to the spillover and direction of FDI. These aspects 
can roughly be introduced as intra-industry links, intra-industry back and forth links, and vertical cross-industry links. There is evidence that the know-how that FDI has, regardless of its direction, will have a diffusion effect in the host economy and increase overall productivity (Kim et al., 2015; Saggi, 2002). FDI can promote international experience, gains, and an increase in efficiency in industries and the overall productivity in the host country. In this context, a country's economy must attract FDI to facilitate the transfer of information and new technology. According to Ngoc et al. (2009), the technology-dimensional spillover effect of FDI is divided into two in the literature as (i) intra-industry/horizontal spillovers and (ii) interindustry/vertical spillovers. It draws attention that intra-industry/horizontal spreads, being divided into three main branches, are as follows: (1) demonstration effects, (2) competition effects, and (3) labor mobility effects. According to the study; Demonstration effects express the effect of learning by imitation and watching. Competition effects The indirect effect of FDI on the productivity and innovation of the host country through intensified competition is also a form of spillover effect. Labor mobility effects occur when workers and managers working in foreign subsidiaries are trained with advanced technical and managerial skills move to other domestic companies or open their businesses. Study (ii) indicates that crossindustry/vertical spillovers occur as an interaction between foreign and domestic firms that are not in the same industry.

In the theoretical literature, the prevailing opinion is that foreign direct investments trigger growth in host countries via improving efficiency and productivity (Dritsaki et al., 2004, Borensztein et al., 1998; Makki and Somwaru, 2004). However, empirical studies have not been able to prove this consensus. The evidence in the studies shows that FDI has a positive effect on the productivity of the host countries or companies in question. However, empirical studies differ in the direction and shape of the said positive effect. On the other hand, the impact of increases and decreases in FDI on productivity may not be symmetrical. According to Anwar and Sun (2014: 23), where they examine the nature of FDI-related productivity spillovers in the Chinese manufacturing industry, the size of spillovers depends on firm age, capital density and ownership structure. They found that the size of productivity spillovers depends on firm size and product quality.

Unlike the theoretical definitiveness of FDI spillovers, many empirical studies examining productivity spillovers fail to find conclusive evidence. Most studies for developing and transitional economies either fail to find significant positive effects or even uncover evidence of negative intra-industry effects (i.e., horizontal effects). FDI often harms local firms by increasing competitive pressure and taking market share away from firms in the host economy. Fortunately, evidence of positive vertical effects in developing economies seems to be more effective in empirical studies than in previous literature, which generally finds that local suppliers to foreign buyers are the prime beneficiaries of FDI inflows. To sum up, 
the wisdom derived from the previously-conducted studies tells us that asymmetric FDI spillovers have positive vertical effects but negative horizontal ones (Jeon et al., 2013). In other words, FDI can promote international experience, gains, and increasing efficiency in industries and the overall productivity in the host country. In this context, a country's economy must attract FDI to facilitate the transfer of information and new technology.

In the light of the findings of existing studies on the subject analyzing the nexus of FDI and productivity in the literature, the main hypothesis of this study asserts that incoming FDI and labor productivity are positively correlated in a non-linear manner in the long term in Turkey from 1987 to 2018. This study identifies a longrun nonlinear relationship between FDI and labor productivity. In this context, it contributes to further scientific research and the literature, especially by addressing the long-term asymmetric relationship between FDI and labor productivity and using macro-level data specific to Turkey for the first time in the literature

The remaining part of the study consists of five sections. Section 2 obtains a brief literature review on the issue. We explain the theoretical background of the methodology employed to conduct our analyses in Section 3. The data utilized in the research are described and clarified along with tabulated estimation results in Section 4. Section 5 provides a detailed discussion of the empirical findings, and the last part concludes.

\section{Literature Review}

FDI plays a vital role in the economic development of countries with capital, advanced technology and knowledge gap. These countries compete fiercely to bring more FDI to their countries. The basic expectations of these countries are the increase in welfare. However, the fact is that an increase in welfare arises from an increase in productivity. The literature displays a wide range in terms of both productivity and FDI.

Regarding productivity, in their study utilizing panel data set covering 19892008 and 19 transition economies, three labor productivity indicators, and six privatization indicators, Yilmaz and Yalçınkaya Koyuncu (2018) point out that privatization increases productivity in transition economies. In their analysis using the cross-section data of 111 countries and Ordinary Least Square (OLS) estimation technique for different samples of 1997-2006 period, Yidirim et al. (2009) reveal that labor productivity decreases as the air temperature rises in a country. The study by Koyuncu Yalcinkaya et al. (2016) displays that labor productivity will increase with female labor force participation. Using annual observations from 162 countries, Koyuncu Yalcinkaya et al. (2017) found a positive relationship between 
internet penetration and productivity. The relationship between corruption and labor productivity is also examined by Koyuncu Yalçınkaya and Ünver (2018).

Regarding FDI, Koyuncu et al. (2016) empirically analyzed the impact of IQ level on FDI using a cross-section data of 184 countries and two different FDI indicators. They point out that countries with higher IQ levels experience higher FDI entry. Tax incentives also contribute to the increase of FDIs. The corporate tax incentive is a policy used by many countries to attract FDIbecause FDI can increase efficiency and economic growth in host countries. Deng et al. (2012) display that removing tax incentives prevents productivity and spillovers of FDI and undermines foreign presence, vital for FDI productivity and spread. The relationship between judicial independence and the FDI, analyzed by Koyuncu Yalcinkaya (2011) and another study by Ito (2005), emphasizes that attracting FDI will also contribute to urban and spatial development.. The estimation results of the Koyuncu Yalcinkaya and Ünver's (2019) study show that infrastructure has a positive statistically significant impact on FDI inflows.

In this study, we empirically investigate whether there exists a non-linear long-term relationship between FDI and productivity for the period of 1987-2018 in Turkey. Therefore, it is essential to draw attention to the studies in the literature especially examining the relationship between FDI and productivity.

The research of the relationship between FDIs and productivity has been widely and in-depth conducted for transition economies (Elmawazini et al., 2018), EU countries (Derado and Horvatin, 2019; Vassilis and Jacob, 2010), Central and Eastern European countries (Bijsterbosch and Kolasa, 2010), Gulf Cooperation Organization Member countries (Elmawazini, 2014), Sub-Sharan Africa countries (Asongu et al., 2020), and developing countries (Herzer and Donaubauer, 2018). Koyuncu and Çinar (2009) covered the period 1980-2005 in Turkey for 26 observations with the help of co-integration analysis. Previously, they had investigated the long-term relationship between productivity and trade openness and then tested the relationship between productivity and foreign direct investment in the same way. Accordingly, the end of the 20 year-period of trade openness explains $38.7 \%$ of workforce productivity, while foreign direct investments explain $19.3 \%$ of workforce productivity. The relationship between FDI and productivity is also examined based on effects: the effect of FDI on labor productivity (Pripoaie, 2017; Karentina, 2019), on firm-level productivity (Chen et al., 2019; Rashmi, 2004; Vinish, 2002; Fukunari and Kozo, 2006), on industry efficiency (Wang, 2012; Kim, 2015; Khalifah et al., 2020), and the productivity of sub-sectors (Lin et al., 2020; Sheereen et al., 2015; Jin et al., 2017; Souare, 2013).

Economic growth is a result of the interaction of labor, capital, and technology. In this context, FDI contributes not only with its funds but also intangible assets (technology and technical information) contribute to the increase in productivity of 
the host country (Derado and Horvatin, 2019). Derado and Horvatin (2019) point out that innovative FDIs have much stronger positive effects in technologically less developed economies. Eric and Malick (2010), which draws attention to a different dimension of productivity growth, emphasize that the contributions of FDIs from various countries may differ significantly due to the sophisticated differences in technology/knowledge, managerial practices, motives, and strategic approaches in host countries. Wang (2010) supports this view in his study in which he argues that FDI brings not only new investments that increase national income but also secondary spillovers that lead to an increase in productivity in the host economy. Wang (2010) argues that in the world, the majority of FDI mainly originates from multinational enterprises in developed countries, and multinationals devote a significant amount of resources to research and development (R\&D).

Fillat and Woerz (2011) tested the relationship between FDI and productivity growth for 35 countries covering the period of 1987-2002. They take into account the heterogeneity of host countries and their industries. They concluded that the most important is a positive relationship between FDI and productivity for some industries and host countries if FDI has a high investment or export orientation.

Bijsterbosch and Kolasa (2010) display the impact of FDI entry on the productivity convergence in Central and Eastern Europe with four different results. First, it has a strong convergence effect on productivity at both the country and industry levels. Secondly, FDI entry plays a crucial role in calculating productivity increases. Third, the impact of FDI on productivity is critically dependent on the absorption capacity of the host countries and their industries. Fourth, there is significant heterogeneity between countries, industries, and time for some key findings. Demir and Duan (2018) investigated the effects of bilateral FDI flows on host country productivity growth and productivity convergence dynamics. Using bilateral FDI flows' data from 108 hosts and 240 home countries over 1990-2012, they found no significant effect of bilateral FDI flows on either host country productivity growth or on the productivity gap between the host and the frontier country. These findings are not sensitive to the direction of FDI flows, which are South-South, South-North, NorthSouth, or North-North. However, they found some evidence of a positive effect of FDI flows on human capital growth only in the South-South direction. They also failed to find any productivity growth or convergence effect at the sectoral level, including agricultural, industrial, or services sectors.

Demena and Van Bergeijk (2017) reviewed the heterogeneity of productivity spillovers caused by FDI in 31 developing countries through a more comprehensive data set. Having analyzed 1450 spillover estimates of 69 empirical studies published in 1986-2013, they came across the inconsistencies in the reported spillover findings affected by publication bias, the data, estimation techniques, and empirical specification. Their findings show that reported FDI spillover estimates are affected by publication bias. Their results emphasize that spillovers and their sign largely 
depend systematically on specification characteristics of the primary studies and publication bias. They pinpoint the fact that future research should cover more developing countries. Not only should they investigate whether spillovers occur but also how spillovers emerge.

There are many studies that analyze the effect of FDI at the firm level. Singh (2017) reviewed the literature and investigated the relationship between FDI and the productivity of firms for the period between 1974 and 2013. When it comes to family businesses, it is revealed that there is no improvement in productivity due to their risky approach and limited strategic aggressiveness. It is also observed that labor productivity does not change when unskilled labor is employed. Kimura and Kiyota (2006) focused on FDI and firm productivity using panel data for Japanese firms. They find that the most productive and moderately efficient companies are exporting and searching for FDI while the least productive companies are focused only on the domestic market. In addition, firms that maintain their presence in foreign markets through FDI demonstrate that they show the highest productivity growth, thus contributing to the improvement of national productivity. Evaluating firms according to the upper, middle, and lower efficiency category, Girma et al. (2005) point out that the firms with the highest efficiency find it profitable to cover the costs associated with FDI, while the less efficient firms can only serve the domestic market. They demonstrate that the productivity distribution of multinational firms involving FDI is dominant in the direction of exporter firms.

Firms' decisions regarding FDI also affect the relationship between FDI and productivity. Therefore, it will be useful to examine the studies in this direction in the literature. Jordaan (2005), who provided statistical evidence on FDI-related externalities in the Mexican manufacturing industries for 1993, reveals that the magnitude of the technological differences between FDI and Mexican firms is in a positive relationship with externalities, which is not effective on incentives and adverse competition for investments that facilitate externality. Damijan et al. (2007) test three empirical hypotheses that relate the decision for outward FDI to total factor productivity by using a data set of Slovenian manufacturing firms active in the period 1994-2002 that contains information on outward FDI and exports to different markets. The evidence supports the hypothesis that more productive firms are more likely to invest in a foreign affiliate. Second, the hypothesis that less productive firms can be encouraged to invest in low-income countries is rejected by the data. However, the main contribution of the study to the literature is the existence of a positive relationship between the number of foreign affiliates of a firm and the total factor productivity.Tomiura (2007), which deals with a firmlevel dataset covering all manufacturing industries in Japan, concluded that foreign outsourcers and exporters tend to be less productive than the firms active in FDI but more productive than domestic firms even when firm size, factor intensity, and/or industry are controlled for. Vahter (2011) investigated different channels 
through which FDI affects domestic firms and whether FDI affects knowledge sourcing activities, innovation, and productivity growth of domestic firms by employing firm-level panel data from Estonia's manufacturing sector. He found no evidence of an impact of FDI entry on the short-term productivity growth of local incumbents. However, he found a positive relationship between the entry of FDI and the direct measures of spillovers. He argues that FDI inflow to a sector is closely related to more knowledge flows to domestic firms and an increase in their innovation activities.

Barbosa and Eiriz (2009) examined whether foreign firms generate productivity spillovers by using firm-level data over the 1994-1999 period in the Portuguese manufacturing industry. Their results suggest that foreign firms in the same industry, being the observed firms (horizontal spillovers), and linkages between foreign firms and their local suppliers or customers (vertical spillovers) do not impact significantly the productivity of firms. However, they failed to detect differences in productivity spillovers associated with firm-specific characteristics. Fauzel et al. (2015) investigated whether FDI in the manufacturing sector enhances the productivity sector in Mauritius. Their results indicate that FDIs in the manufacturing industry contributes to both total factor productivity and labor productivity in the long run. When the short-term results of the study are analyzed, it is revealed that FDI in the manufacturing sector continues to affect efficiency, but the effect is minimal. Their results also confirm the presence of bi-causality and feedback effects in the FDI-Productivity relationship.

Teixeira and Shu (2012) focused on the relationship between FDI, productivity, and economic growth in China. Based on a set of large and innovative firms (national and foreign capital) located in China, they concluded that the direct impact of foreign capital on the level of human capital in firms is negative suggesting that FDI has a positive influence on their human capital. They also concluded that FDI has a positive impact on general human capital (i.e. formal education) by means of investment in R\&D. They argue that these results suggest that it is necessary to implement a selective policy to attract FDI for China to benefit from FDI by taking into account more technologically advanced, R\&D-based projects. In their studies analyzing the development of long and short-term labor productivity for the Chinese provinces between 1978 and 2010, Mitze and Özyurt (2014) present that FDI has a direct impact on labor productivity in addition to internal factors such as investment intensity and infrastructure utilization. However, Driffield and Love (2007), who empirically examined the effects of FDIs on the UK's domestic productivity, state that inward FDIs, which are motivated by technology suppliers, do not cause productivity increases. Similarly, Zhang (2002) states that FDIs have certain effects on labor productivity, but this effect is not very strong and important. Therefore, according to Zhang, the contribution of FDIs to China's technological progress through technology transfer is still not fully noticed. 


\section{Methodology}

ARDL model proposed by Pesaran et al. (2001) is one of the most preferred methods in the literature for cointegration analysis since, unlike the conventional cointegration methods, it allows regressors for being I(0), I(1), or mixed. In our case, the ARDL model can be depicted as below:

$$
\begin{aligned}
& \Delta \text { PROD }_{t}=\mu+\delta_{1} \text { PROD }_{t-1}+\delta_{2} \mathrm{FDIINW}_{t-1}+\delta_{3} \mathrm{INVEST}_{t-1}+\delta_{4} \mathrm{HOUR}_{t-1}+ \\
& +\delta_{5} \mathrm{GDPPC}_{t-1}+\sum_{i=1}^{p-1} \beta_{i} \Delta P R O D_{t-i}+\sum_{i=0}^{q-1} \alpha_{i} \Delta \mathrm{FDIINW}_{t-i}+\sum_{i=0}^{s-1} \phi_{i} \Delta I N V E S T_{t-i}+ \\
& +\sum_{i=0}^{r-1} \theta_{i} \Delta \text { HOUR }_{t-i}+\sum_{i=0}^{w-1} \gamma_{i} \Delta \text { GDPPC }_{t-i}+\varepsilon_{t}
\end{aligned}
$$

where the notations of $\delta_{1}, \delta_{2}, \delta_{3}, \delta_{4}, \delta_{5}$ terms represent long-run coefficients; $\beta_{i}, \alpha_{i}$, $\phi_{i}, \theta_{i}, \gamma_{i}$ terms represent short-term coefficients; $\Delta$ is first degree difference operator; $\mu$ is constant term, and $\varepsilon_{t}$ is white noise error term.

The ARDL model represented in Equation (1) allows for investigating both the short-run and the long-run relationship between productivity and FDI as long as this relationship is linear (i.e., symmetric). On the other hand, when the association between productivity and FDI is nonlinear (i.e., asymmetric) then a model misspecification error will be committed. In order to avoid this potential model misspecification error, a model taking into account asymmetric association between productivity and FDI is required.

Shin et al. (2014) proposed a non-linear NARDL (i.e., NARDL) model accounting for asymmetric relationship between PROD and FDIINW variables. In NARDL approach, FDIINW variable is decomposed into its positive and negative partial sums as follows:

$$
\begin{aligned}
& \text { FDIINW }_{t}^{+}=\sum_{j=1}^{t} \Delta \mathrm{FDIINW}_{t}^{+}=\sum_{j=1}^{t} \max \left(\Delta \mathrm{FDIINW}_{j}, 0\right) \text { and } \\
& \text { FDIINW }_{t}^{-}=\sum_{j=1}^{t} \Delta \mathrm{FDIINW}_{t}^{-}=\sum_{j=1}^{t} \min \left(\Delta \mathrm{FDIINW}_{j}, 0\right)
\end{aligned}
$$

The NARDL representation of our model taking short-run and long-run asymmetries into consideration can be shown as follows:

$$
\begin{aligned}
& \triangle P R O D_{t}=\mu+\delta_{1} \text { PROD }_{t-1}+\delta_{2}^{+} \mathrm{FDIINW}_{t-1}^{+}+\delta_{2}^{-} \mathrm{FDIINW}_{t-1}^{-}+\delta_{3} \mathrm{INVEST}_{t-1}+ \\
& +\delta_{4} \mathrm{HOUR}_{t-1}+\delta_{5} \mathrm{GDPPC}_{t-1}+\sum_{i=1}^{p-1} \beta_{i} \Delta P R O D_{t-i}+\sum_{i=0}^{q-1}\left(\alpha_{i}^{+} \Delta \mathrm{FDIINW}_{t-i}^{+}+\right. \\
& \left.\alpha_{i}^{-} \Delta \mathrm{FDIINW}_{t-i}^{-}\right)+\sum_{i=0}^{s-1} \phi_{i} \Delta I N V E S T_{t-i}+\sum_{i=0}^{r-1} \theta_{i} \Delta H O U R_{t-i}+\sum_{i=0}^{w-1} \gamma_{i} \Delta \text { GDPPC }_{t-i}+\varepsilon_{t}
\end{aligned}
$$


Presence of a long-run asymmetry between productivity and FDI can be checked by testing the null hypothesis of $\mathrm{H}_{0}: \delta_{2}^{+}=\delta_{2}^{-}$. Accepting $\mathrm{H}_{0}$ hypothesis will result in a symmetric long-run association between productivity and FDI while rejecting $\mathrm{H}_{0}$ hypothesis will lead to an asymmetric long-run relationship between productivity and FDI. According to the bound test approach of Pesaran et al. (2001), our null hypothesis for the cointegration test is given by $\mathrm{H}_{0}: \delta_{1}=\delta_{2}^{+}=\delta_{2}^{-}=\delta_{3}=\delta_{4}=\delta_{5}=0$. If the computed F-statistic value exceeds the upper bound value (i.e., $\mathrm{I}_{1}$ ) then we conclude that there is a cointegrating relationship among variables, in other words, the relevant variables move together in the long run. F-statistic value falling below the lower bound value (i.e., $\mathrm{I}_{0}$ ) implies no cointegration, whereas F-statistic value remaining between two bound values leaves us indecisive.

\section{Empirical data and results}

In this study, by performing the Nonlinear Auto-Regressive Distributed Lag (NARDL) analysis for two different productivity indicators for the 1987-2018 period, we empirically investigated whether there is a non-linear long-term relationship between FDI and productivity in Turkey. The period limitation stems from the unavailability of data for years before 1987 for one of the control variables utilized in the analyses.

Incoming FDI may make a positive contribution to productivity of the host country by bringing new advanced technologies, which are more effective and productive relative to previous technologies. However, the nexus of FDI and productivity, rather than being linear, might be non-linear because the impact of increases and decreases in FDI on productivity may not be symmetric. Therefore, we hypothesize that an asymmetric association between FDI and productivity exists in the long run in Turkey.

Two distinct proxies for productivity are employed, namely PROD1 and PROD2. PROD1 is gross value added in terms of per person employed. It is computed as the ratio of gross value added at basic prices (constant 2010 US\$) to persons employed. The data for gross value added and persons employed are gathered from WDI and The Conference Board Total Economy Database respectively. PROD2 is labor productivity per person employed in 2017 US\$ and obtained from The Conference Board Total Economy Database. FDIINW is per capita inward FDI and imputed by dividing inward FDI (US dollars at current prices) with population. FDI data are from UNCTADSTAT while data for the population are collected from WDI.

Besides the FDIINW variable, we employed three control variables (i.e., HOUR, GDPPC, and INVEST) relevant to productivity. The HOUR stands for annual hours worked per worker provided by The Conference Board Total Economy Database. Increasing working hours may lead to rises in productivity, especially for developing economies like Turkey, and hence we expect to have a positive coefficient for the 
HOUR variable. GDPPC is GDP per capita in terms of constant 2010 US\$ and gathered from WDI. GDP per capita reflects the purchasing power and welfare level of individuals in an economy. Therefore, increases in GDP per capita will enhance the working motivation of workers, and eventually, productivity level will rise. A positive coefficient for the GDPPC variable is anticipated. INVEST is gross fixed capital formation in terms of constant 2010 US\$ and represents investments in the economy. The production capacity of an economy goes up as long as the investment level increases in that economy. We expect a positive coefficient for INVEST variable. All variables are in logarithmic forms so that coefficients reflect the elasticities.

Since both ARDL and NARDL approaches do not allow integration order of I (2) or beyond, we firstly performed Phillips-Perron (PP) and Augmented Dickey-Fuller (ADF) unit root tests to figure out integration level of the variables. As indicated by Tables 1 and 2, all variables are stationary at a 1\% significance level, and thus, they meet the requirement of the ARDL and the NARDL approaches. Therefore, we are able to conduct long-run asymmetry analyses via NARDL model.

Table 1: PP Test for Constant\&Linear Trend Model $\left(\mathrm{H}_{0}\right.$ : non-stationary)

\begin{tabular}{|l|c|c|c|c|c|}
\cline { 2 - 5 } \multicolumn{1}{c|}{} & \multicolumn{2}{c|}{ Level } & \multicolumn{2}{c|}{ First Difference } & \multirow{2}{*}{ Integration } \\
\cline { 2 - 5 } \multicolumn{1}{c|}{} & Stat. & Prob. & Stat. & Prob. & \\
\hline INVEST & -2.8171 & 0.2021 & -6.1687 & 0.0001 & $\mathrm{I}(1)$ \\
\hline HOUR & -1.1626 & 0.9014 & -4.7318 & 0.0033 & $\mathrm{I}(1)$ \\
\hline GDPPC & -1.0237 & 0.9263 & -6.4850 & 0.0000 & $\mathrm{I}(1)$ \\
\hline FDIINW & -2.3223 & 0.4107 & -5.7703 & 0.0002 & $\mathrm{I}(1)$ \\
\hline PROD1 & 3.3973 & 0.0695 & -8.0164 & 0.0000 & $\mathrm{I}(1)$ \\
\hline PROD2 & -3.4972 & 0.0567 & -8.1383 & 0.0000 & $\mathrm{I}(1)$ \\
\hline
\end{tabular}

Source: Author's research

Table 2: ADF Test for Constant\&Linear Trend Model $\left(\mathrm{H}_{0}\right.$ : non-stationary)

\begin{tabular}{|l|c|c|c|c|c|}
\cline { 2 - 5 } \multicolumn{1}{c|}{} & \multicolumn{2}{c|}{ Level } & \multicolumn{2}{c|}{ First Difference } & \multirow{2}{*}{ Integration } \\
\cline { 2 - 5 } \multicolumn{1}{c|}{} & Stat. & Prob. & Stat. & Prob. & \\
\hline INVEST & -2.8171 & 0.2021 & -6.0135 & 0.0001 & $\mathrm{I}(1)$ \\
\hline HOUR & -1.7738 & 0.6937 & -4.7460 & 0.0032 & $\mathrm{I}(1)$ \\
\hline GDPPC & -1.0378 & 0.9240 & -5.6779 & 0.0003 & $\mathrm{I}(1)$ \\
\hline FDIINW & -2.2441 & 0.4506 & -5.6422 & 0.0003 & $\mathrm{I}(1)$ \\
\hline PROD1 & -3.3789 & 0.0722 & -7.3822 & 0.0000 & $\mathrm{I}(1)$ \\
\hline PROD2 & -3.4738 & 0.0595 & -7.4741 & 0.0000 & $\mathrm{I}(1)$ \\
\hline
\end{tabular}

Source: Author's research 
Secondly Schwarz information criteria (SIC) is used to choose the optimal lag lengths and the NARDL $(1,0,0,0,1,0)$ model is selected out of 486 models evaluated. Bound test results for nonlinear cointegration for the models where PROD1 and PROD2 are dependent variables are displayed in Table 3 and 4 respectively. As seen from Table 3, calculated F-statistics is higher than upperbound critical values at all significance levels but $1 \%$ significance level for PROD1 model; hence this finding implies that there is a nonlinear cointegrating relationship among relevant variables. In other words, the selected variables move together in the long term.

Table 3: Nonlinear Cointegration Test Results for PROD1 Model

\begin{tabular}{|c|c|c|}
\hline F-statistic: 4.4625 & \multicolumn{2}{|c|}{ CriticalValues } \\
\hline Sig. Level & $I_{0}$ & $I_{1}$ \\
\hline $10 \%$ & 2.49 & 3.38 \\
\hline $5 \%$ & 2.81 & 3.76 \\
\hline $2.50 \%$ & 3.11 & 4.13 \\
\hline $1 \%$ & 3.5 & 4.63 \\
\hline
\end{tabular}

Source: Author's research

As displayed in Table 4, calculated F-statistics is higher than upper-bound critical values at all significance levels for PROD2 model; thus this result hints that selected variables have a co-movement in the long run.

Table 4: Nonlinear Cointegration Test Results for PROD2 Model

\begin{tabular}{|c|c|c|}
\hline F-statistic: 5.7611 & \multicolumn{2}{|c|}{ CriticalValues } \\
\hline Sig. Level & $I_{0}$ & $I_{1}$ \\
\hline $10 \%$ & 2.49 & 3.38 \\
\hline $5 \%$ & 2.81 & 3.76 \\
\hline $2.50 \%$ & 3.11 & 4.13 \\
\hline $1 \%$ & 3.5 & 4.63 \\
\hline
\end{tabular}

Source: Author's research

We thirdly implement Wald test to find out if there exists a long-run asymmetry for PROD1 and PROD2 models by testing the null hypothesis of $\mathrm{H}_{0}: \delta_{2}^{+}=\delta_{2}^{-}$. As seen from Table 5 reporting long-term asymmetry test findings, there is a long-run asymmetry for both PROD1 and PROD2 models at 1\% significance level. This finding confirms the validity of NARDL model relative to ARDL model. 
Yüksel Okşak,Cüneyt Koyuncu • Long-run asymmetric association between FDI...

Table 5: Long-run Asymmetry Test Results

\begin{tabular}{|c|c|c|c|}
\hline \multicolumn{2}{|c|}{ PROD1 } & \multicolumn{2}{c|}{ PROD2 } \\
\hline F-statistic & P-value & F-statistic & P-value \\
\hline 18.3065 & 0.0003 & 15.1581 & 0.0007 \\
\hline
\end{tabular}

Source: Author's research

As indicated by the findings given in Model Diagnostic Tests section, residuals of PROD1 model have a normal distribution and the model does not suffer from autocorrelation or heteroscedasticity problem.

Table 6: NARDL Estimation Results for PROD1 Model

\begin{tabular}{|c|c|c|}
\hline \multicolumn{3}{|l|}{ Short-run Coefficients } \\
\hline & Coefficient & P-value \\
\hline$\Delta$ FDIINW $_{+(t)}$ & 0.0169 & 0.0787 \\
\hline$\Delta$ FDIINW $_{-(t)}$ & -0.0480 & 0.002 \\
\hline$\Delta \mathrm{INVEST}_{(\mathrm{t})}$ & 0.0567 & 0.4243 \\
\hline$\Delta$ HOUR $_{(t)}$ & 0.9810 & 0.0117 \\
\hline$\Delta \mathrm{GDPPC}_{(\mathrm{t})}$ & 0.7780 & 0.0018 \\
\hline Constant & -7.9693 & 0.0001 \\
\hline $\mathrm{ECM}_{(t-1)}$ & -0.6903 & 0.0001 \\
\hline \multicolumn{3}{|l|}{ Long-run Coefficients } \\
\hline & Coefficient & P-value \\
\hline FDIINW $^{+}$ & 0.0165 & 0.0669 \\
\hline FDIINW $^{-}$ & -0.0559 & 0.0162 \\
\hline INVEST & 0.0709 & 0.4356 \\
\hline HOUR & 2.5828 & 0.0001 \\
\hline GDPPC & 0.8537 & 0.0078 \\
\hline Trend & -0.0143 & 0.0337 \\
\hline \multicolumn{3}{|l|}{ Model Diagnostic Tests } \\
\hline & test-statistic & $P$-value \\
\hline ARCH Heteroskedasticity Test & 0.2951 & 0.5911 \\
\hline B-G Serial Correlation LM Test & 0.3768 & 0.6906 \\
\hline Jarque-Bera test on normality & 1.3263 & 0.5152 \\
\hline
\end{tabular}

Source: Author's research 
Moreover, as can be seen from Figure 1 displaying the CUSUM of the squares test result, since the movement lies within the 5\% significance lines, it suggests that parameters are stable in the PROD1 model.

Figure 1: CUSUM-Square Parameter Stability Test for PROD1 Model

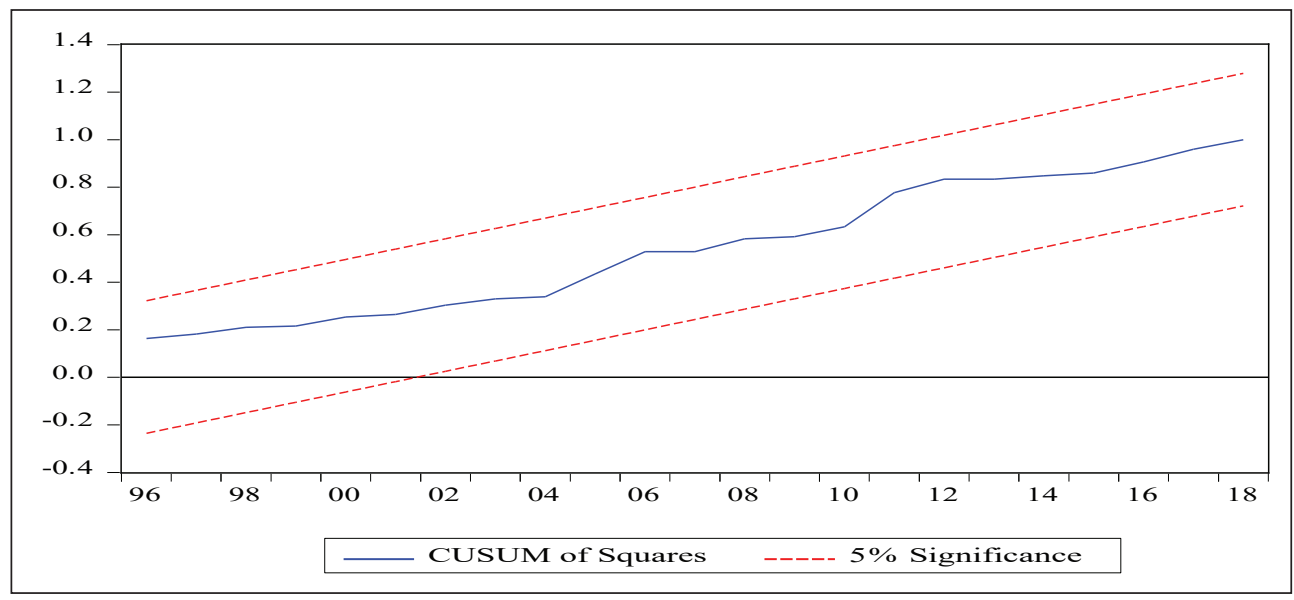

Source: Author's research

Model Diagnostic Tests findings also indicate that residuals of PROD2 model are distributed normally and the model does not have autocorrelation or heteroscedasticity problem.

Figure 2: CUSUM-Square Parameter Stability Test for PROD2 Model

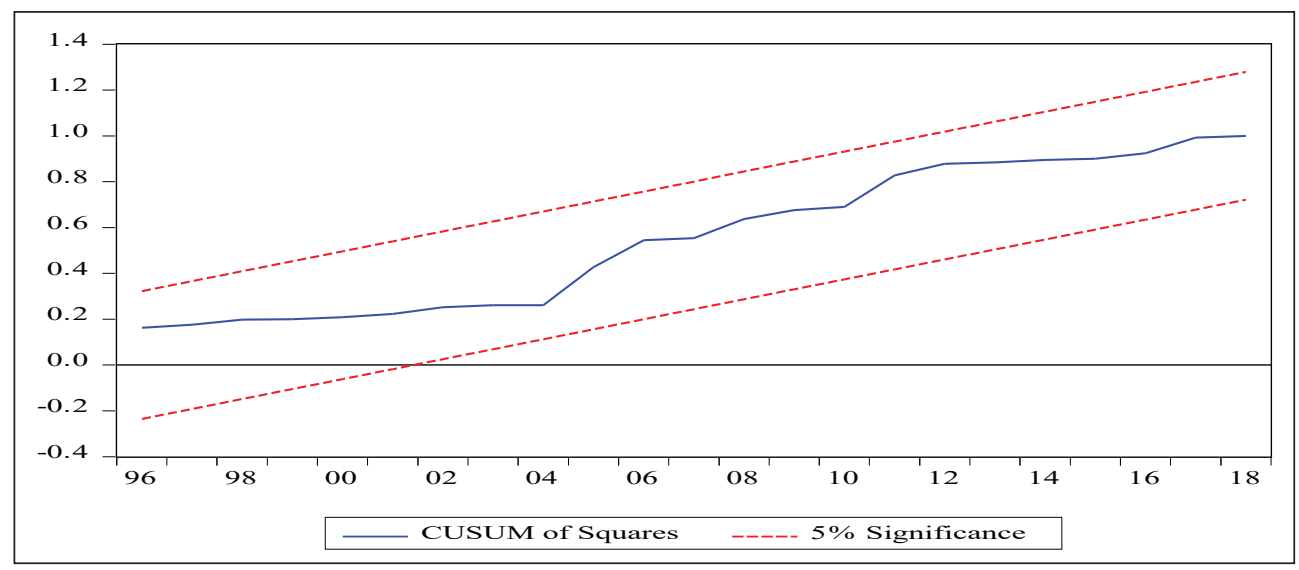

Source: Author's research 
Yüksel Okşak,Cüneyt Koyuncu • Long-run asymmetric association between FDI...

Table 7: NARDL Estimation Results for PROD2 Model

\begin{tabular}{|c|c|c|}
\hline \multicolumn{3}{|l|}{ Short-run Coefficients } \\
\hline & Coefficient & P-value \\
\hline$\Delta$ FDIINW $_{+(t)}$ & 0.0186 & 0.0549 \\
\hline$\Delta$ FDIINW $_{-(\mathrm{t})}$ & -0.0414 & 0.006 \\
\hline$\Delta$ INVEST $_{(\mathrm{t})}$ & 0.1306 & 0.0795 \\
\hline$\Delta \mathrm{HOUR}_{(\mathrm{t})}$ & 0.9636 & 0.0142 \\
\hline$\Delta \mathrm{GDPPC}_{(\mathrm{t})}$ & 0.5423 & 0.0263 \\
\hline Constant & -12.3353 & 0.0001 \\
\hline $\mathrm{ECM}_{(\mathrm{t}-1)}$ & -0.9106 & 0.0001 \\
\hline \multicolumn{3}{|l|}{ Long-run Coefficients } \\
\hline & Coefficient & P-value \\
\hline FDIINW $^{+}$ & 0.0201 & 0.0135 \\
\hline FDIINW $^{-}$ & -0.0402 & 0.0458 \\
\hline INVEST & 0.1204 & 0.1495 \\
\hline HOUR & 2.1053 & 0.0002 \\
\hline GDPPC & 0.6287 & 0.0258 \\
\hline Trend & -0.0097 & 0.0961 \\
\hline \multicolumn{3}{|l|}{ Model Diagnostic Tests } \\
\hline & test-statistic & $P$-value \\
\hline ARCH Heteroskedasticity Test & 0.4111 & 0.5265 \\
\hline B-G Serial Correlation LM Test & 1.1501 & 0.3357 \\
\hline Jarque-Bera test on normality & 0.1333 & 0.9355 \\
\hline
\end{tabular}

Source: Author's research

CUSUM of squares test result in Figure 2 implies parameters of PROD2 model are stable since the movement stays inside the $5 \%$ significance lines.

\section{Results and discussion}

Lastly, long-term estimation results are shown in Tables 6 and 7. Table 6 displays the findings for the model where PROD1 (i.e., gross value added in terms of per person employed) is a dependent variable. Error correction term (ECM) takes the anticipated negative sign and is highly statistically significant. The coefficient of ECM reflects how strongly the dependent variable responds to a deviation from the equilibrium relationship stemming from a shock in one period, or it is nothing more than how fast such an equilibrium distortion is recovered. The ECM coefficient indicates that any deviation from the long-run equilibrium will be eliminated 
within a period shorter than two years. In addition, the ECM coefficient with a higher value than -1 in the PROD1 model hints stability of the PROD1 model. The positive and negative long-run asymmetric coefficient estimations, given by FDIINW+ and FDIINW- are statistically significant at least at a $10 \%$ significance level. According to the estimation findings, in the long run in Turkey, when the incoming per capita FDI increases by $1 \%$ gross value added in terms of per person employed goes up by $0.0165 \%$ whereas when the incoming per capita FDI goes down by $1 \%$ gross value added in terms of per person employed drops by $0.0559 \%$. Long-term coefficients of HOUR and GDPPC variables possess the expected signs and are highly significant. An increase of $1 \%$ in working hours causes a $2.5828 \%$ enhancement in gross value added in terms of per person employed while a rise of $1 \%$ in per capita GDP makes a $0.8537 \%$ contribution to gross value added in terms of per person employed in the long run in Turkey.

Table 7 reports the estimation results for the model where PROD2 (i.e., labor productivity per person employed) is a dependent variable. Error correction term (ECM) of the model gets the expected negative sign and is highly significant. The ECM coefficient points out that any deviation from the long-run equilibrium will be eliminated in less than one year. Meanwhile, the ECM coefficient with a value higher than -1 in the PROD2 model hints at the stability of the PROD2 model. Positive and negative long-run asymmetric coefficient estimations, given by FDIINW+ and FDIINW- are statistically significant at least at a 5\% significance level. As can be deducted from estimated long-run coefficients of FDIINW+ and FDIINW- variables, when the incoming per capita FDI goes up by $1 \%$, labor productivity per person employed rises by $0.0201 \%$ while, when the incoming per capita FDI goes down by $1 \%$, labor productivity per person employed falls by $0.0402 \%$ in Turkey. Long-run coefficients of HOUR and GDPPC variables take the anticipated signs and are statistically significant at least at a 5\% significance level. If working hours go up by $1 \%$, then labor productivity per person-employed rises by $2.1053 \%$; on the other hand, an increase of $1 \%$ in per capita GDP leads to a rise of $0.6287 \%$ in labor productivity per person employed in the long run in Turkey.

In addition to the studies emphasizing that there is no significant relationship between FDI and labor productivity, there are also studies showing a negative relationship. Some studies suggest that FDI is not only an investment but is also creating employment and brings along the much-needed technological advances, or has a crowding-out effect. Therefore, such studies emphasize the positive relationship between FDI and Labor productivity and try to explain the source of this relationship with the spillover effect. The results of this paper obtained in the study also support this situation. As mentioned earlier, it is emphasized that there is a positive relationship between FDI and labor productivity in a non-linear manner in the long term in Turkey. An increase in working hours causes an enhancement in gross value added in terms of per person employed while a rise in per capita 
GDP makes a contribution to gross value added in terms of per person employed in the long run in Turkey. If working hours go up then labor productivity per personemployed rises; on the other hand, an increase in per capita GDP leads to a rise in labor productivity per person employed in the long run in Turkey.

Our hypothesis claims the existing asymmetric association between FDI and productivity in the long run in Turkey. Nonlinear cointegration test findings indicate that selected variables are cointegrated, moving together in the long run. The obtained results contribute to bridging a significant gap by bringing a different perspective to the relevant literature. Our study uses aggregated data at a macro level to analyze the long-term asymmetric relationship between foreign direct investment and labor productivity in Turkey using the NARDL estimation technique.

\section{Conclusion}

This study explores both short-run and the long-run asymmetric association between incoming FDI and labor productivity in Turkey. Following this purpose, the nonlinear autoregressive distributed lag (NARDL) model is employed and estimated. Concerning the estimation results, a long-run nonlinear relationship between incoming FDI and labor productivity was detected and this finding remained valid across two models constructed by using two distinct labor productivity indicators. Therefore estimation results acknowledge the validity of our main hypothesis. Short-run coefficients of the FDI variable are significant and take the expected signs in both models. Moreover per capita GDP and working hours, in parallel to prior expectations, positively affect labor productivity in both short-run and long-run whereas investment does not have a significant impact on labor productivity. In other words, an increase in GDP per capita leads to a rise in labor productivity by enhancing the working motivation of laborers, and an increase in working hours induces a rise in labor productivity by increasing output per labor in both the short-run and long run in Turkey. As a whole, our results are consistent with the ones found in the literature. Besides, for the first time in the literature, this study addresses the long-run asymmetric nexus between FDI and labor productivity by using macro-level data specific to Turkey. The results of this study contain several policy implications. To improve and maintain long-run sustainable labor productivity, the Turkish government should implement practice policies and legislative regulations necessary for promoting inward FDI. Encouraging inward FDI not only enhances labor productivity but also boosts up economic growth through the transmission mechanism. The Turkish government also should support and adopt policies augmenting per capita GDP, which is a rough indicator of an individual's welfare level. The impact of inward FDI on labor productivity in Turkey should be further studied in future researches by implementing the 
same analysis for the manufacturing sector, industrial sector, agricultural sector, and sector of services. In addition to that different data set in terms of variable combination or estimation techniques can be employed to see how the results vary.

\section{References}

Anwar, S., Sun, S. (2014) "Heterogeneity and curvilinearity of FDI-related productivity spillovers in China's manufacturing sector", Economic Modelling, Vol. 41, pp. 23-32, https://doi.org/10.1016/j.econmod.2014.03.021.

Asongu, S. A., Nnanna, J., Acha-Anyi, P. N. (2020) "On the simultaneous openness hypothesis: FDI, trade and TFP dynamics in Sub-Saharan Africa", Journal of Economic Structures: The Official Journal of the Pan-Pacific Association of Input-Output Studies (PAPAIOS), Vol. 9, No. 1, https://doi.org/10.1186/s40008020-0189-4.

Barbosa, N., Eiriz, V. (2009) "Linking corporate productivity to foreign direct investment: An empirical assessment", International Business Review, Vol. 18, No. 1, pp. 1-13, https://doi.org/10.1016/j.ibusrev.2008.10.003.

Bijsterbosch, M., Kolasa, M. (2010) "FDI and productivity convergence in Central and Eastern Europe: an industry-level investigation", Review of World Economics / Weltwirtschaftliches Archiv, Vol. 145, No. 4, pp. 689-712, https:// doi.org/10.1007/s10290-009-0036-z.

Borensztein, E., De Gregorio, J., \& Lee, J. W. (1998) How does foreign direct investment affect economic growth?. Journal of international Economics, 45(1), 115-135, https://doi.org/10.1016/S0022-1996(97)00033-0.

Carp, L. (2013) "Anaysis of the relationship between fdi and economic growthliterature review study", The USV Annals of Economics and Public Administration, Vol. 12, No. 15, pp. 154-160, http://www.annals.seap.usv.ro/ index.php/annals/article/view/467/460.

Chen Ting Gui, L. G., Yabe, M. (2019) "Impact of outward FDI on firms' productivity over the food industry: evidence from China", China Agricultural Economic Review, Vol. 11, No. 4, pp. 655-671, https://doi.org/10.1108/CAER12-2017-0246.

Damijan, J. P., Polanec, S., Prašnikar, J. (2007) "Outward FDI and Productivity: Micro-evidence from Slovenia", World Economy, Vol. 30, pp. 135-155, doi: 10.1111/j.1467-9701.2007.00876.x.

Demir, F., Duan. Y. (2018) "Bilateral FDI Flows, Productivity Growth, and Convergence: The North vs. The South", World Development, Vol. 101, pp. 235-249, https://doi.org/10.1016/j.worlddev.2017.08.006.

Deng, Z., Falvey, R., Blake, A. (2012) "Trading market access for technology? Tax incentives, foreign direct investment and productivity spillovers in China", 
Journal of Policy Modeling, Vol. 34, No. 5, pp. 675-690, https://doi. org/10.1016/j.jpolmod.2012.01.003.

Derado, D., Horvatin, D. (2019) "Does Fdi Mode of Entry Have an Impact on the Host Country's Labor Productivity? An Analysis of the Eu Countries", Ekonomski Vjesnik, Vol. 32, No. 2, pp. 405-423, https://www.proquest.com/ scholarly-journals/does-fdi-mode-entry-have-impact-on-host-countrys/ docview/2335125988/se-2?accountid=17219.

Demena, B.A., van Bergeijk, P.A.G. (2017) "A META-ANALYSIS OF FDI AND PRODUCTIVITY SPILLOVERS IN DEVELOPING COUNTRIES”, Journal of Economic Surveys, Vol. 31, pp. 546-571, doi: 10.1111/joes.12146.

Driffield, N., Love, J. H. (2007) "Linking FDI motivation and host economy productivity effects: conceptual and empirical analysis", Journal of international business studies, Vol. 38, No. 3, pp. 460-473, https://doi.org/10.1057/palgrave. jibs. 8400268 .

Dritsaki, M., Dritsaki, C., Adamopoulos, A. (2004) "A causal relationship between trade, foreign direct investment and economic growth for Greece", American Journal of applied sciences, Vol. 1, No. 3, pp. 230-235, https://core.ac.uk/ download/pdf/25903151.pdf.

Elmawazini, K. (2014) "FDI Spillovers, Efficiency Change and Host Country Labor Productivity: Evidence from GCC Countries", Atlantic Economic Journal, Vol. 42, No. 4, https://doi.org/10.1007/s11293-014-9428-0.

Elmawazini, K. et al. (2018) "Tripartite decomposition of labor productivity growth, FDI and human development: evidence from transition economies", Economic Change and Restructuring: Empirical and Policy Research on the Transitional and Emerging Economies, Vol. 51, No. 2, https://doi.org/10.1007/ s10644-016-9197-7.

Eller, M., Haiss, P., Steiner, K. (2006) "Foreign direct investment in the financial sector and economic growth in Central and Eastern Europe: The crucial role of the efficiency channel", Emerging Markets review, Vol. 7, No. 4, pp. 300-319, https://doi.org/10.1016/j.ememar.2006.09.001.

Erdogan, A. (2011) "Foreign direct investment and productivity spillovers: evidence from Turkey", Journal of Applied Finance \& Banking, Vol. 1, No. 4, https:// ssrn.com/abstract $=2369151$.

Eric C.Y. Ng, Souare, M. (2010) "Inward FDI and Productivity Performance in Canadian Industries: Does the Country of Origin Matter?", Transnational Corporations Review, Vol. 2, No. 3, pp. 72-90, doi: 10.1080/19186444. 2010.11658251.

Fatima, S. T. (2016) "Productivity spillovers from foreign direct investment: evidence from Turkish micro-level data", The Journal of International Trade \& Economic Development, Vol. 25, No. 3, pp. 291-324, https://doi.org/10.1080/09 638199.2015.1050057. 
Fauzel, S., Seetanah, B., Sannasee, R. V. (2015) "Productivity Spillovers of FDI in the Manufacturing Sector of Mauritius. Evidence from a Dynamic Framework", Journal of Developing Areas, Vol. 49, No. 2, pp. 295-316, https://doi. org/10.1353/jda.2015.0026

Fillat, C., Woerz, J. (2011) "Good or bad? The influence of FDI on productivity growth. An industry-level analysis", The Journal of International Trade \& Economic Development, Vol. 20, No. 3, pp. 293-328, doi: 10.1080/09638190903003010.

Flora, P., Agrawal, G. (2017) "FDI and economic growth nexus for the largest FDI recipients in Asian emerging economies: a panel co-integration analysis", In International Business Strategy (pp. 261-275). Palgrave Macmillan, London. https://doi.org/10.1057/978-1-137-54468-1_12.

Fukunari, K., Kozo, K. (2006) "Exports, FDI, and Productivity: Dynamic Evidence from Japanese Firms", Review of World Economics / Weltwirtschaftliches Archiv, Vol. 142, No. 4, https://doi.org/10.1007/s10290-006-0089-1.

Girma, S., Kneller, R., Pisu, M. (2005) "Exports versus FDI: An Empirical Test", Rev. World Econ., Vol. 141, pp. 193-218, https://doi.org/10.1007/s10290-0050025-9.

Herzer, D., Donaubauer, J. (2018) “The long-run effect of foreign direct investment on total factor productivity in developing countries: a panel cointegration analysis", Empirical Economics: Journal of the Institute for Advanced Studies, Vol. 54, No. 2, https://doi.org/10.1007/s00181-016-1206-1.

Hübler, M., Keller, A. (2010) "Energy savings via FDI? Empirical evidence from developing countries", Environment and Development economics, Vol. 15, No. 1, pp. 59-80, https://www.jstor.org/stable/44379001.

Ito, Y. (2015) "Is starting FDI more productive than staying at home? Manufacturing and service sectors in Japan", Journal of International Trade \& Economic Development, Vol. 24, No. 1, pp. 105-131, https://doi.org/10.1080/09638199.20 13.877064 .

Jeon, Y., Park, B. I., Ghauri, P. N. (2013) "Foreign direct investment spillover effects in China: Are they different across industries with different technological levels?", China Economic Review, Vol. 26, pp. 105-117. https://oi.org/ 10.1016/j.chieco.2013.05.001.

Jin S. et al. (2017) "Benefit or damage? The productivity effects of FDI in the Chinese food industry", Food Policy, Vol. 68, pp. 1-9, https://doi.org/10.1016/j. foodpol.2016.12.005.

Jordaan, J. A. (2005) "Determinants of FDI-induced externalities: New empirical evidence for Mexican manufacturing industries", World Development, Vol. 33, No. 12, pp. 2103-2118, https://doi.org/10.1016/j.worlddev.2005.07.007.

Karentina, R. (2019) "The spillover effects of foreign direct investment on labor productivity", Economic Journal of Emerging Markets, Vol. 1, No. 32, https:// doi.org/10.20885/ejem.vol11.iss1.art4. 
Khalifah, N. A., Salleh, S. M., Adam, R. (2020) "FDI productivity spillovers and the technology gap in Malaysia's electrical and electronic industries", AstanPacific Economic Literature, Vol. 29, No. 1, pp, 142-160, https://oi.org/ 10.1111/apel.12094.

Kim, H. H., Lee, H., Lee, J. (2015) "Technology diffusion and host-country productivity in South-South FDI flows", Japan and the world Economy, Vol. 33, pp. 1-10, https://doi.org/10.1016/j.japwor.2014.11.001.

Kim, M. (2015) "Productivity spillovers from FDI and the role of domestic firm's absorptive capacity in South Korean manufacturing industries", Empirical Economics: Journal of the Institute for Advanced Studies, Vol. 48, No. 2, https:// doi.org/10.1007/s00181-014-0804-z.

Kimura, F., Kiyota, K. (2006) "Exports, FDI, and Productivity: Dynamic Evidence from Japanese Firms", Rev. World Econ., Vol. 142, pp. 695-719, https://doi. org/10.1007/s10290-006-0089-1.

Koyuncu, C., Çınar, İ., T. (2009) “Ticari Dışa Açıklık Ve Doğrudan Yabancı Sermaye Yatırımlarının İşgücü Verimliliğine Etkisi: 1980 - 2005 Türkiye Uygulaması", Atatürk Üniversitesi İktisadi ve İdari Bilimler Dergisi, Vol. 23, No. 1, pp. 309-326, https://dergipark.org.tr/en/pub/atauniiibd/issue/2695/35498.

Koyuncu, C. et al. (2016) "Is IQ Level of a Country Important to Attract More FDI?: Cross-country Evidence", The Empirical Economics Letters, Vol. 15, No. 12, pp. 1179-1188.

Koyuncu Yalcinkaya, J. (2011) "Yargı Bağımsızlığı, Mülkiyet Hakkı ve Yolsuzluğun Yabancı Sermaye Girişleri Üzerindeki Etkisi", Dumlupınar Üniversitesi Sosyal Bilimler Dergisi, Vol. 29, Retrieved from https://dergipark. org.tr/en/pub/dpusbe/issue/4771/65658.

Koyuncu Yalcikaya, J., et al. (2016) "The Relationship Between Female Labor Force Participation and Labor Productivity: Panel Data Analysis". Eskişehir Osmangazi Üniversitesi İ̈BF Dergisi, Vol. 11, No. 2, pp. 237-249. https://www. researchgate.net/profile/Mustafa-Unver/publication/309348316_The Relationship_Between_Female_Labor_Force_Participation_and_Labor_ Productivity_Panel_Data_Analysis/links/580c872c08ae2cb3a5da7266/TheRelationship-Between-Female-Labor-Force-Participation-and-LaborProductivity-Panel-Data-Analysis.pdf.

Koyuncu Yalcinkaya, J., Ünver, M. (2018) "Does Corruption Deteriorate Labor Productivity? Panel Evidence" in Studies on Balkan and Near Eastern Social Sciences, Vol. 2, Edited by Rasim Yilmaz and Günther Löschnigg, pp. 159-169, Berlin: PETER LANG, ISBN 978-3-631-74727-8.

Koyuncu Yalcinkaya, J., Ünver, M. (2019) "Revisiting the Nexus of Infrastructure and FDI: The Case of Transition Economies", Balkan and Near Eastern Journal of Social Sciences, Vol. 3, No. 4, pp. 150-156, https://www.researchgate.net/ profile/Mustafa-Unver/publication/322037262_Revisiting_the_Nexus_of_ 
Infrastructure_and_FDI_The_Case_of_Transition_Economies/ links/5a3f8523458515f6b0463d1d/Revisiting-the-Nexus-of-Infrastructure-andFDI-The-Case-of-Transition-Economies.pdf.

Koyuncu Yalcikaya, J. et al. (2017) "Internet Penetration and Productivity: A Panel Study”. Anadolu Üniversitesi Sosyal Bilimler Dergisi, Vol. 17, No. 1, pp. 5966, https://dergipark.org.tr/en/pub/ausbd/article/415638.

Lin, B. et al. (2020) "The impact of foreign direct investment on the productivity of the Chinese forest products industry", Forest Policy and Economics, Vol. 111, https://doi.org/10.1016/j.forpol.2019.102035.

Makki, S. S., Somwaru, A. (2004) "Impact of foreign direct investment and trade on economic growth: Evidence from developing countries", American journal of agricultural economics, Vol. 86, No. 3, pp. 795-801, http://www.jstor.org/ stable/3697825.

Mitze, T., Özyurt, S. (2014) "The Spatial Dimension of Trade- and FDI-driven Productivity Growth in Chinese Provinces: A Global Cointegration Approach", Growth \& Change, Vol. 45, No. 2, pp. 263-291, https://doi.org/10.1111/ grow. 12042 .

Ngoc Anh, N., et al. (2009) "Foreign direct investment in Vietnam: is there any evidence of technological spillover effects; research report", https://idl-bncidrc.dspacedirect.org/handle/10625/39598.

Nguyen, A. N., Nguyen, T. (2008) "Foreign direct investment in Vietnam: Is there any evidence of technological spillover effects", Available at SSRN 1117202, http://dx.doi.org/10.2139/ssrn.1117202.

Nistor, P. (2015) "FDI implications on BRICS economy growth", Procedia Economics and Finance, Vol. 32, pp. 981-985, https://doi.org/10.1016/S22125671(15)01557-9.

Osano, H. M., Koine, P. W. (2016) "Role of foreign direct investment on technology transfer and economic growth in Kenya: a case of the energy sector", Journal of Innovation and Entrepreneurship, Vol. 5, No. 1, pp. 1-25, https://doi. org/10.1186/s13731-016-0059-3.

Pesaran, M. H., Shin, Y., Smith, R. J. (2001) "Bounds testing approaches to the analysis of level relationships", Journal of Applied Econometrics, Vol. 16, No. 3, pp. 289-326, doi: 10.1002/jae.616.

Pripoaie, R. (2017) "Statistical Analysis of the Evolution FDI Comparative with Growth Rate of Labour Productivity per Employed Person and Growth Rate of GDP per Capita", Acta Universitatis Danubius: Oeconomica, Vol. 6, https:// www.ceeol.com/search/article-detail?id=730619.

Rashmi, B. (2004) "Impact of Japanese and US FDI on Productivity Growth: A Firm-Level Analysis", Economic and Political Weekly, Vol. 39, No. 5, https:// www.jstor.org/stable/4414579. 
Rong, S. et al. (2020) "FDI, labor market flexibility and employment in China", China Economic Review, Vol. 61, https://doi.org/10.1016/j.chieco.2020.101449.

Saggi, K. (2002) "Trade, foreign direct investment, and international technology transfer: A survey", The World Bank Research Observer, Vol. 17, No. 2, pp. 191-235, https://doi.org/10.1093/wbro/17.2.191.

Sheereen F., Seetanah, B., Sannasee, R. V. (2015) "Productivity Spillovers of Fdi in the Manufacturing Sector of Mauritius. Evidence from a Dynamic Framework", The Journal of Developing Areas, Vol. 49, No. 2, https://www.jstor.org/ stable/24241308.

Shin Y., Yu B., Greenwood-Nimmo M. (2014) "Modelling Asymmetric Cointegration and Dynamic Multipliers in a Nonlinear ARDL Framework" In: Sickles R., Horrace W. (eds.) Festschrift in Honor of Peter Schmidt. Springer, New York, NY, pp. 281-314, doi: 10.1007/978-1-4899-8008-3_9.

Singh, A. P. (2017) "Does FDI Promote Productivity? A Deep Dive", Indian Journal of Industrial Relations, Vol. 52, No. 3, pp. 443-455, https://www.jstor.org/ stable/26536408.

Souare, M. (2013) "Productivity growth, trade and FDI nexus: evidence from the Canadian manufacturing sector", The Journal of Technology Transfer, Vol. 38, No. 5, https://doi.org/10.1007/s10961-012-9259-6.

Soumaré, I. (2015) "Does FDI improve economic development in North African countries?", Applied Economics, Vol. 47, No. 51, pp. 5510-5533, https://doi.org/ 10.1080/00036846.2015.1051655.

Teixeira, A. C., Shu, L. (2012) "The level of human capital in innovative firms located in China. Is foreign capital relevant?", Journal of the Asia Pacific Economy, Vol. 17, No. 2, pp. 343-360, https://doi.org/10.1080/13547860.2012. 668095.

Tomiura, E. (2007) "Foreign outsourcing, exporting, and FDI: A productivity comparison at the firm level", Journal of International Economics, Vol. 72, No. 1, pp. 113-127, https://doi.org/10.1016/j.jinteco.2006.11.003.

Wang, Y. (2010) "FDI and productivity growth: the role of inter-industry linkages", Canadian Journal of Economics/Revue canadienne d'économique, Vol. 43, pp. 1243-1272, doi:10.1111/j.1540-5982.2010.01613.x.

Wang, Y. (2012) "Openness and Productivity: The Role of Imports, FDI and International Telecommunications", Latin American Journal of Economics, Vol. 49, No. 1, http://dx.doi.org/10.4067/S0719-04332012000100005.

Vahter, P. (2011) "Does FDI Spur Productivity, Knowledge Sourcing and Innovation by Incumbent Firms? Evidence from Manufacturing Industry in Estonia", The World Economy, Vol. 34, pp. 1308-1326, doi:10.1111/j.1467-9701.2011.01379.x.

Vassilis, M., Jacob, A. J. (2010) "Does FDI promote regional development? Evidence from local and regional productivity spillovers in Greece", Eastern 
Journal of European Studies, Vol. 2, https://www.ceeol.com/search/articledetail $?$ id $=519350$.

Vinish K. (2002) "Liberalisation, FDI, and Productivity Spillovers: An Analysis of Indian Manufacturing Firms", Oxford Economic Papers, Vol. 54, No. 4, https:// doi.org/10.1093/oep/54.4.688.

Yildirim, K., Koyuncu, C., Koyuncu, J. (2009) "Does temperature affect labor productivity: Cross-country evidence", Applied Econometrics and International Development, Vol. 9, No. 1, pp. 29-39, https://www.researchgate.net/profile/ Cuneyt-Koyuncu/publication/227410116_Does_Temperature_Affect_Labor_ Productivity_Cross-Country_Evidence/links/0a85e53467d19369e8000000/ Does-Temperature-Affect-Labor-Productivity-Cross-Country-Evidence.pdf.

Yılmaz, R, Yalçınkaya Koyuncu, J. (2018) "The Impact of Privatization on Labor Productivity in Transition Economies and the Turkic Republics", Bilig, Vol. 85, pp. 257-281, Retrieved from https://dergipark.org.tr/en/pub/bilig/issue/36704/518765.

Zhang, Z. (2002) "Productivity and economic growth: an empirical assessment of the contribution of FDI to the Chinese economy", Journal of Economic Development, Vol. 27, No. 2, pp. 81-94, https://www.researchgate.net/profile/ Zhaoyong-Zhang/publication/227450303_Productivity_and_economic growth_an_empirical_assessment_of_the_contribution_of_FDI_to_the Chinese_economy/links/00b4951 f328c0d4b4a000000/Productivity-andeconomic-growth-an-empirical-assessment-of-the-contribution-of-FDI-to-theChinese-economy.pdf.

Zhang, K. H. (2005) "Why does so much FDI from Hong Kong and Taiwan go to Mainland China?", China Economic Review, Vol. 16, No. 3, pp. 293-307, https://doi.org/10.1016/j.chieco.2005.02.004. 


\title{
Dugoročna asimetrična povezanost između izravnih stranih ulaganja i produktivnosti u Turskoj
}

\author{
Yüksel Okşak ${ }^{1}$, Cüneyt Koyuncu ${ }^{2}$
}

\begin{abstract}
Sažetak
Izravna strana ulaganja (FDI) mogu povećati razinu produktivnosti zemlje domaćina uvođenjem novih naprednih tehnologija. S druge strane, veza između izravnih stranih ulaganja i produktivnosti, umjesto da je linearna, može biti nelinearna zbog toga što je moguće da učinak povećanja i smanjenja izravnih stranih ulaganja na produktivnost nije simetričan. U tom smislu, ova studija istražuje asimetrični odnos između izravnih stranih ulaganja i produktivnosti u Turskoj a koriste se dva različita pokazatelja produktivnosti (tj. PROD1 i PROD2) i primjenjuje nelinearni ARDL pristup. Naša hipoteza tvrdi da je dugoročno u Turskoj prisutna asimetrična povezanost između izravnih stranih ulaganja $i$ produktivnosti. Nalazi testa nelinearne kointegracije pokazuju da su odabrane varijable kointegrirane i stoga se dugoročno kreću zajedno. Naša studija koristi prikupljene podatke na makro razini kako bi se analizirao dugoročni asimetrični odnos između izravnih stranih ulaganja $i$ produktivnosti rada u Turskoj uz primjenu NARDL tehnike procjene. Što se tiče rezultata procjene, utvrđena je dugoročna nelinearna veza između ulaznih izravnih stranih ulaganja $i$ produktivnosti rada, a ovaj je nalaz ostao valjan u dva modela konstruirana korištenjem dva različita pokazatelja produktivnosti rada. U cjelini, naši su rezultati u skladu s onima koji se nalaze u literaturi. Osim toga, po prvi put u literaturi, ova se studija bavi dugoročnim asimetričnim vezama između izravnih stranih ulaganja i produktivnosti rada korištenjem podataka na makro razini specifičnim za Tursku te daje različite političke preporuke.
\end{abstract}

Ključne riječi: produktivnost, FDI (izravna strana ulaganja), radno vrijeme, investicije, GDPPC, NARDL

JEL klasifikacija: C22, E22, F21, J24

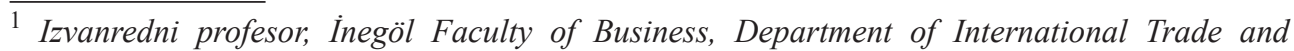
Business, Bursa Uludağ University, 16400 Inegöl/Bursa, Turska. Znanstveni interes: makroekonomski razvoj, rast, zaposlenost, ekonometrijsko modeliranje. ORCID: 0000-00018794-4597.yukseloksak@uludag.edu.tr.

2 Prof., Faculty of Economics and Administrative Sciences, Department of Economics, Bilecik Şeyh Edebali University, 11230 Merkez/Bilecik, Turska. Znanstveni interes: primijenjena ekonomija, panel analiza, ekonometrijsko modeliranje. ORCID: 0000-0002-8638-2761. cuneyt.koyuncu@bilecik.edu.tr 